\title{
Capture of Anastrepha sororcula (Diptera: Tephritidae) in McPhail and Jackson Traps with Food Attractant and Virgin Adults
}

\author{
Christiane dos Santos Felix ${ }^{1 *}$, Manoel Araécio Uchôa-Fernandes ${ }^{1}$ and Odival Faccenda ${ }^{2}$ \\ ${ }^{1}$ Laboratório de Insetos Frugívoros; Universidade Federal da Grande Dourados; C.P.: 24; 79804-970, Dourados - \\ MS - Brasil. ${ }^{2}$ Laboratório de Insetos Frugivoros; Universidade Federal da Grande Dourados; C.P.: 24; 79804- \\ 970; Dourados - MS - Brasil. ${ }^{3}$ Departamento de Computação; Universidade Estadual de Mato Grosso do Sul;C.P.: \\ 35; 79804-970; Dourado - MS - Brasil
}

\begin{abstract}
This study evaluated the capture of A. sororcula in the traps baited with the conspecific virgin adults and food attractant in two orchards. The first was the Orchard of the Universidade Federal da Grande Dourados (OUFGD) and the second, the Orchard of the Sindicato Rural de Dourados (OSRD). The capture of A. sororcula in McPhail and Jackson traps was carried out using the corn hydrolysed protein (CHP), control (no flies), virgin males (5, 10 and 15), five virgin females and five virgin couples. The average number of the flies caught in the traps with the corn hydrolysed protein was significantly higher than all the other treatments. There was no significant capture of A. sororcula females in the traps baited with the conspecific virgin males, females or the couples.
\end{abstract}

Key words: Sexual attraction, Fruit fly, Guava orchard

\section{INTRODUCTION}

Studies about the fruit flies are mandatory in all the countries in which the fruit production is commercially explored since these insects are the key pests in the fruit plantations. In the global terms, it is estimated that the direct and indirect losses caused by the fruit flies exceed the amount of two billion dollars/year. The tephritids are the most serious problem in the horticulture worldwide and the main factor that prevents natural fruits from being commercialized all over the world (R. A. Zucchi, pers. comm.).
In Brazil, the losses in fruit production due to the high control costs of the fruit flies and the loss of the export market vary between 120 and 200 million dollars annually. There is practically no country with a minimally organized agriculture which has no legislation about quarantine barriers to fruit flies (R. A. Zucchi, pers.comm.). Among the fruits cultivated for the commercial purposes, the economic importance of the guava (Psidium guajava L., 1753) has increased since it is used on natural and also in the processing industries in diverse forms (Gonzaga-Neto, 2001; Cboudbury, 2001; Matias et al., 2005).

\footnotetext{
* Author for correspondence: felixbio@bol.com.br
} 
The fruit flies are one of the most serious pests in guava plantations. Anastrepha sororcula Zucchi (1979), A. fraterculus (Wiedemann, 1830) and A. zenildae Zucchi (1979) are the main species associated with this fruit species (Barbosa, 2001); A. sororcula is predominant in the state of Mato Gosso do Sul, Brazil (Uchôa-Fernandes et al., 2003). Although the guava is economically important due to its high aggregate values (1.5 to 2 dollars $/ \mathrm{kg}$ ) in the local market, there is little research done related to the fruit fly population management. The chemical control has shown to be a routinely used method (Barbosa, 2001). However, since the fruit fly larvae develop inside the fruits, the chemical pesticide effects are significantly diminished.

The use of the pheromones has been highlighted as an important tool for the Integrated Pest Management of different insect species. The use of the sex pheromone in the sticky traps is an efficient method of monitoring several pests. However, studies are still necessary for the development of the strategies of the monitoring and control of the fruit flies with the pheromone traps (Vilela and Della Lucia, 2001).

The behavioral studies are necessary, including the chemical communication of Anastrepha species for the implementation of the synthetic pheromone-based traps in the monitoring and/or populational control of Anastrepha flies in the field. The aim of this work was to evaluate the capture of A. sororcula in the traps baited with the food attractant and virgin adults in two different environments.

\section{MATERIAL AND METHODS}

\section{Study areas}

The bioassays were carried out from January to April, 2005. The adults were obtained from the guava fruits collected in the field and were kept under a $12 \mathrm{~h}$ photoperiod (6 a.m. to $6 \mathrm{p}$.m.). The field assay was conducted in the orchards of the Universidade Federal da Grande Dourados (OUFGD), (22 $2^{\circ} 11^{\prime} 46^{\prime \prime} \mathrm{S}$ and $\left.54^{\circ} 55^{\prime} 59^{\prime \prime} \mathrm{W}\right)$ and the Sindicato Rural de Dourados-MS (OSRD), $\left(22^{\circ} 13^{\prime} 34^{\prime \prime} \mathrm{S}\right.$ and $\left.54^{\circ} 43^{\prime} 55^{\prime \prime} \mathrm{W}\right)$. The OUFGD comprised 4.0 ha, was surrounded by the pasture areas, and had the following fruit trees: mango (Mangifera indica L.), Surinam cherry (Eugenia uniflora L.), avocado (Persea americana Mill.), Spanish prune (Spondias purpurea L.), tamarind
(Tamarindus indica L.), jaboticaba (Myrciaria cauliflora Berg), banana (Musa spp.), guava (Psidium guajava L.), rose apple (Eugenia jambos L.), Plum (Prunus domestica L.), star fruit (Averrhoa carambola L.), persimmon (Diospyros kaki L.), jackfruit (Artocarpus integrifolia L.), grape (Vitis vinifera L.), fig (Ficus carica L.), West Indian cherry (Malpighia emarginata D. C.), peach (Prunus persica L.), lemon (Citrus sp.), "castanha-do-maranhão", (Bombacopsis glabra Pasq. A. Rob.) and coffee (Coffea arabica L.). During the study period, the following plants bore the fruit: guava, mango, grape, avocado, star fruit and jaboticaba.

The orchard of the Sindicato Rural de Dourados (2.5 ha), located near a native riparian forest, had the following host plants: peach, fig, guava, mango, custard apple (Annona squamosa L.), soursop (Annona muricata L.), banana, coconut (Cocos nucifera L.), and grape. Guava and the fig trees had fruits throughout all the field experiments. The weather data such as temperature, relative humidity, rainfall and wind speed were obtained from the weather station of Embrapa Agropecuária Oeste, Dourados-MS, 15 $\mathrm{km}$ from the orchard of UFGD and $10 \mathrm{~km}$ from the orchard of Sindicato Rural.

\section{A. sororcula adults for the bioassay}

The adults of $A$. sororcula were obtained from the guava fruits naturally infested and collected in the region of Dourados-MS. The fruits were kept in the laboratory for 40 days so that all the frugivorous larvae could complete their development, as proposed by Uchôa-Fernandes and Zucchi (1999). The $3^{\text {rd }}$ instar larvae were collected on an interval of $12 \mathrm{~h}$, placed in the transparent acrylic recipients $(300 \mathrm{~mL})$ containing the sterilized sand moistened with the drinking water until the completion of the pupal stage and adult emergence. The newly emerged adults were removed from the acrylic cages, separated by the sex and kept in the cages in different environments. The cages were built by the transparent PET bottles $(25 \mathrm{~cm}$ height X $10 \mathrm{~cm}$ diameter) covered with the voil cloth and kept at $26^{\circ} \mathrm{C}$ and $70 \%$ relative humidity. The flies were fed the drinking water and an artificial diet (Salles, 1992) containing $100 \mathrm{~g}$ of the brown sugar, 500 $\mathrm{mL}$ hydrolyzed protein, $100 \mathrm{~mL}$ sterilized water and $10 \mathrm{~g}$ honey. 


\section{Capture of A. sororcula with Jackson and McPhail traps}

Seven Jackson traps and seven McPhail traps were set up in the field within $30 \mathrm{~m}$ from each other. Sexually mature males (7 to 12 days old) and females (14 days old) (Facholi-Bendassolli and Uchôa-Fernandes, 2006) were tested as an attractant in the traps. The males, the females and the couples were kept in the metallic cages $(4.0 \mathrm{~cm}$ x $2.0 \mathrm{~cm} \mathrm{x} 2.0 \mathrm{~cm}$ ) covered with the elastic fabric and fixed in the interior of the traps. Each Jackson trap received a card smeared with Biocontrole ${ }^{\circledR}$ entomological glue. The cards were placed on the bottom of the traps in order to retain the insects attracted by the odor source. In the Jackson traps, a piece of cotton was moistened with the hydrolyzed protein Tephritid ${ }^{\circledR}$ and was inserted in a plastic lid and placed inside the cage. The cotton was moistened with the hydrolyzed protein every morning. The traps with the hydrolyzed protein were used to check the presence of the fruit flies in the orchard.Two bioassays were carried out in the two orchards, each one set up at the ends of each orchard. The first bioassay was installed with the Jackson traps involving the following treatments: 1) control (no flies), 2) five virgin males, 3) 10 virgin males, 4) 15 virgin males, 5) five couples, 6) hydrolyzed corn protein $(10 \% \mathrm{v} / \mathrm{v})$ and 7$)$ five virgin females. Thus, in each of the four collecting points of the experiment, a total of 35 males and 10 females were used. In the second bioassay, McPhail traps were used, also with the hydrolyzed corn protein $(10 \% \mathrm{v} / \mathrm{v})$. The same proceedure of the first bioassay was followed. The McPhail and Jackson traps were hung at about $1.6 \mathrm{~m}$ from the soil level under the shadow of fruit trees and randomly distributed.

The traps had a piece of the cotton moistened in drinking water, which was placed on the floor of the cages. The adults that occasionally died in the interior of the traps were substituted by others of the same age. All the flies used as the bait, as well as the ones captured by the traps, were placed in recipients with alcohol $70 \%$ and identified.

\section{Data Analysis}

This study analyzed three variables: the baits, traps and locality in relation to the average number of the captured adults of $A$. sororcula at the four collecting points. The same procedure was repeated for seven days for all the treatments. Kruskal-Wallis and Mann-Whitney tests were used in order to compare the hypothesis of the equality between the averages of the treatments and for the multiple comparisons a posteriori among the averages. The correlation index of Pearson was used to verify if the number of the adults of $A$. sororcula, captured in the McPhail and Jackson traps presented any relationship to the climatic factors. All the results were analyzed considering the significance level of $5 \%$ of the probability.

\section{RESULTS AND DISCUSSION}

The number of the adults of A. sororcula captured in the OUFGD and in the OSRD was low during most of the sampling period (Table 1).

For both the traps, the average number of $A$. sororcula adults caught with the hydrolyzed protein was significantly higher $(\mathrm{p}<0.05)$ in comparison to the other treatments (Table 2). When the number of $A$. sororcula flies captured in both the orchards was separately analyzed, McPhail traps with the hydrolyzed protein captured a significantly higher number of $A$. sororcula flies, in comparison to the other treatments with the conspecific adults. In the Jackson traps with the hydrolyzed protein, although a higher number of $A$. sororcula adults were caught in relation to the other baits and McPhail traps, no significant differences were detected $(p>0.05)$ between the treatments (Table 2).

Although, the temperature has been considered important in the population behavior of the flies (Tardelli et al., 2004), the average number of $A$. sororcula, captured in the OUFGD and the OSRD orchards, did not show any significant difference when related to the different climatic variables. The result showed that the climatic variables did not interfere in the capture of $A$. sororcula adults, according to the correlation analysis of Pearson: temperature $(\mathrm{r}=0.087 ; \mathrm{p}=0.225)$, relative humidity $(\mathrm{r}=-0.058 ; \mathrm{p}=0.423)$, rainfall $(\mathrm{r}=$ $0.096 ; \mathrm{p}=0.183)$ or wind speed $(\mathrm{r}=-0.077 ; \mathrm{p}=$ 0.281). During the experimental period, the temperature ranged between $24^{\circ}$ to $28^{\circ} \mathrm{C}$, the relative humidity (\%RH) between $51 \%$ to $82 \%$, rainfall (accumulated weekly average) from 0 to $19 \mathrm{~mm}$, and the wind speed varied between 3.7 and $13.4 \mathrm{~m} / \mathrm{s}$. 
Table 1 - Number of adults of Anastrepha sororcula captured in two commercial guava orchards in the region of Dourados-MS, Brazil (from February to April, 2005).

\begin{tabular}{|c|c|c|c|c|c|c|c|c|c|}
\hline \multicolumn{10}{|c|}{ Period } \\
\hline \multirow[t]{2}{*}{ Local } & \multirow[t]{2}{*}{ Treatments } & \multicolumn{2}{|c|}{$\begin{array}{c}19 \text { to } \\
\text { 25/February/2005 }\end{array}$} & \multicolumn{2}{|c|}{$\begin{array}{c}5 \text { to } \\
\text { 11/March/2005 }\end{array}$} & \multicolumn{2}{|c|}{$\begin{array}{c}22 \text { to } \\
\text { 25/March/2005 } \\
\end{array}$} & \multicolumn{2}{|c|}{$\begin{array}{c}17 \text { to } \\
\text { 23/April/2005 } \\
\end{array}$} \\
\hline & & Jackson & McPhail & Jackson & McPhail & Jackson & McPhail & Jackson & McPhail \\
\hline \multirow{7}{*}{$\frac{\hat{a}}{0}$} & Control & 0 & 0 & 0 & 0 & 0 & 0 & 0 & 0 \\
\hline & 5 males & 0 & 0 & 0 & 0 & $3(P)$ & 0 & 0 & 0 \\
\hline & 10 males & 0 & 0 & 0 & $1(\overbrace{}^{\lambda})$ & 0 & $1(\widehat{\jmath})$ & $1(+)$ & 0 \\
\hline & 15 males & 0 & 0 & 0 & $1(P)$ & 0 & 0 & 0 & $2(11 ㅅ)$ \\
\hline & 5 couples & 0 & 0 & 0 & 0 & 0 & $1(ㅇ)$ & $1(9)$ & 0 \\
\hline & Protein & 0 & 0 & 0 & $2(+)$ & 0 & $16\left(8+8{ }^{\Uparrow}\right)$ & $8(4+4 \lesssim)$ & $19\left(9+10 \delta^{\lambda}\right)$ \\
\hline & 5 females & 0 & 0 & 0 & 0 & 0 & $1(P)$ & 0 & $1($ P $)$ \\
\hline \multirow{7}{*}{$\begin{array}{l}0 \\
0 \\
0 \\
0\end{array}$} & Control & 0 & 0 & 0 & 0 & 0 & 0 & 0 & 0 \\
\hline & 5 males & 0 & 0 & 0 & 0 & 0 & 0 & 0 & 0 \\
\hline & 10 males & 0 & 0 & 0 & 0 & 0 & $1($ ふ) & 0 & 0 \\
\hline & 15 males & 0 & 0 & 0 & 0 & 0 & $2\left(ठ^{\Uparrow}\right)$ & 0 & 0 \\
\hline & 5 couples & 0 & 0 & 0 & $1($ q $)$ & 0 & 0 & $1(q)$ & $1(ठ)$ \\
\hline & Protein & 0 & 0 & $5(q)$ & $3(+)$ & 0 & $2(q)$ & $5(3 \bigcirc 2 \widehat{\jmath})$ & $25\left(15+10{ }^{\lambda}\right)$ \\
\hline & 5 females & 0 & $1(0)$ & 0 & 0 & 0 & 0 & 0 & 0 \\
\hline
\end{tabular}

Table 2 - Average number of adults of A. Sororcula captured in McPhail and Jackson traps with differents types of attractive in relation to the number of captured individuals in two commercial guava orchars in the region of Dourados - MS.

\begin{tabular}{|c|c|c|c|c|c|c|c|c|c|}
\hline \multicolumn{6}{|c|}{$\begin{array}{l}\text { Answer variable: Average number of captured flies (Standard Deviation) } \\
\text { (Repetitions) }\end{array}$} & \multicolumn{4}{|c|}{ Krusskal-Wallis Multiple comparisons } \\
\hline $\begin{array}{l}\text { Traps } \backslash \\
\text { Bait }\end{array}$ & $\begin{array}{l}\mathbf{a}= \\
\text { protein }\end{array}$ & & $\begin{array}{l}\mathrm{c}=5 \\
\text { male }\end{array}$ & $\begin{array}{l}\mathrm{d}=10 \\
\text { male }\end{array}$ & & $\begin{array}{c}\mathbf{f}=\mathbf{5} \\
\text { couples }\end{array}$ & & $\mathbf{X}^{2}(\mathbf{P})$ & $\begin{array}{c}\text { Mann- } \\
\text { Whitney }\end{array}$ \\
\hline $\begin{array}{c}\text { McPhlail } \\
\text { and } \\
\text { Jackson }\end{array}$ & $\begin{array}{c}0.76 \\
(1.11)(28)\end{array}$ & $\begin{array}{c}0.00 \\
(0.00)(28)\end{array}$ & $\begin{array}{c}0.03 \\
(0.08)(28)\end{array}$ & $\begin{array}{c}0.01 \\
(0.05)(28)\end{array}$ & $\begin{array}{c}0.02 \\
(0.07)(28)\end{array}$ & $\begin{array}{c}0.04 \\
(0.09)(28)\end{array}$ & $\begin{array}{c}0.03 \\
(0.08)(28)\end{array}$ & & $\begin{array}{c}\mathrm{a}>\mathrm{b}=\mathrm{c}=\mathrm{d} \\
=\mathrm{e}=\mathrm{f}=\mathrm{g}\end{array}$ \\
\hline MacPhlail & $\begin{array}{c}1.20 \\
(1.34)(14)\end{array}$ & $\begin{array}{c}0.00 \\
(0.00)(14)\end{array}$ & $\begin{array}{c}0.00 \\
(0.00)(14)\end{array}$ & $\begin{array}{c}0.00 \\
(0.00)(14)\end{array}$ & $\begin{array}{c}0.04 \\
(0.09)(14)\end{array}$ & $\begin{array}{c}0.04 \\
(0.09)(14)\end{array}$ & $\begin{array}{c}0.05 \\
(0.11)(14)\end{array}$ & $\begin{array}{l}29.638 \\
(0.000)\end{array}$ & $\begin{array}{c}\mathrm{a}>\mathrm{b}=\mathrm{c}=\mathrm{d} \\
=\mathrm{e}=\mathrm{f}=\mathrm{g}\end{array}$ \\
\hline Jackson & $\begin{array}{c}0.32 \\
(0.62)(14)\end{array}$ & $\begin{array}{c}0.00 \\
(0.00)(14)\end{array}$ & $\begin{array}{c}0.05 \\
(0.11)(14)\end{array}$ & $\begin{array}{c}0.02 \\
(0.07)(14)\end{array}$ & $\begin{array}{c}0.04 \\
(0.09)(14)\end{array}$ & $\begin{array}{c}0.04(0.09) \\
(14)\end{array}$ & $\begin{array}{c}0.00 \\
(0.00)(14)\end{array}$ & $\begin{array}{l}20.213 \\
(0.003)\end{array}$ & $\begin{array}{c}\mathrm{a}=\mathrm{b}=\mathrm{d}=\mathrm{e} \\
=\mathrm{g}\end{array}$ \\
\hline
\end{tabular}

The average number of $A$. sororcula adults, captured in the orchard of the Sindicato Rural $(0.14 \pm 0.47)$ with both the traps using the hydrolyzed protein, was significantly higher $(\mathrm{Z}=$ 2.19; $\mathrm{p}=0.029)$ than in the OUFGD $(0.11 \pm 0.52)$. The higher population of $A$. sororcula found in the OSRD could probably be due to the fact that this orchard was surrounded by a native riparian forest reserve. The wild hosts in this environment could be a repository for $A$. sororcula populations during the inter harvest period. Conversely, the orchard of UFGD, which was surrounded by the pasture areas, probably did not offer alternative hosts to $A$. sororcula during the inter harvest period.

The fruit fly males are believed to be responsible for releasing the sexual pheromones for the attraction of conspecific females for mating and copulation (Nation, 1989; Vilela and Della Lucia, 2001). Although in Mexico the capture of the females of $A$. suspensa in the traps with the virgin males has been reported (Perdomo et al., 1975, 1976), the results of this stady showed that despite the fact that the males inside the cages showed quick wing vibration movements and extrusion of 
the anal pouch, the capture of the females of $A$. sororcula in the traps with the conspecific virgin males was not significant. The observations of the wing vibration behavior inside the cages was similar to that described by Facholi-Bendassolli and Uchôa-Fernandes (2006), who characterized A. sororcula sound emission during the calling behavior. During the calling behavior the male fruit flies start wing fan movements, probably to direct the air jet above the abdominal surface and extrude the anal pouch. These actions would increase the body temperature and also help in the pheromone dispersion (Nation, 1989). The fruit odors can also completely inhibit the sexual attraction to the male pheromone in active females (Robacker and Garcia, 1990). The volatiles released by $A$. sororcula males remain still unknown and there is no information whether they are chemically similar to those released by the preferential host plants (Myrtaceae) or not.

In the analysis considering the setup with all the treatments regarding the two trap models (McPhail and Jackson), the numbers of the adults caught in the McPhail traps $(1.2 \pm 1.34)$ and in the Jackson traps $(0.3 \pm 0.62)$ were not significantly different $(\mathrm{Z}=1.5 ; \mathrm{p}=0.13)$. According to Bressan et al. (1991), the spherical shape of the traps, associated with the yellow color, was more attractive to the females than to the males of Anastrepha species. Bressan et al. (1991) also observed that the traps with the yellow spheres were able to capture a higher number of $A$. fraterculus females in comparison to the number of the males.

In this study, results indicated that although there was no significant difference between the tested models, McPhail traps (yellow and semi-spheric) captured almost four times more individuals of $A$. sororcula than Jackson traps (Table 1). This suggested that in the experiments involving the adults as a source of the natural pheromones in the field, visual stimulus (yellow color) and the trap shape (semi-spheric) should be considered regarding the attraction of $A$. sororcula males.

\section{ACKNOWLEDGMENTS}

We thank Mr. João Batista Ferreira for his help in the field; Prof. José Adjailson Uchôa-Fernandes, Dr. Janisete Gomes da Silva-Miller and Prof. Elsbeth A. Flunker (WI, USA) for help in reviewing the manuscript; $\mathrm{CNPq}$ for the grant to the first author; Fundação de Apoio ao
Desenvolvimento do Ensino, Ciência e Tecnologia do Estado de Mato Grosso do Sul (FUNDECT) for the financial support (Edital 01/2000, Process 41/100126/2003).

\section{RESUMO}

As moscas-das-frutas constituem um grupo de pragas responsáveis por grandes prejuízos econômicos à fruticultura mundial. Anastrepha sororcula Zucchi, é a principal espécie de tefritídeo que ataca a goiaba em Mato Grosso do Sul. O objetivo desta pesquisa foi avaliar a captura de adultos de $A$. sororcula em armadilhas com atrativo alimentar e adultos virgens, em dois ambientes. Os bioensaios iniciaram-se com a criação de A. sororcula no Laboratório de Insetos Frugívoros da Universidade Federal da Grande Dourados (UFGD). As pesquisas de campo foram desenvolvidas nos pomares da UFGD e do Sindicato Rural de Dourados (SRD)-MS. A captura de adultos de A. sororcula em armadilhas McPhail e Jackson foi avaliada para os tratamentos: proteína hidrolisada de milho, testemunha (sem moscas), machos virgens (5, $10 \mathrm{e}$ 15), 5 fêmeas virgens e 5 casais. $O$ número médio de indivíduos capturados nas armadilhas com proteína foi significativamente maior que nos demais tratamentos. $\mathrm{O}$ número médio de adultos de $A$. sororcula, capturado com o tratamento proteína no SRD foi significativamente superior ao do pomar da UFGD. Não ocorreu captura significativa de fêmeas de $A$. sororcula nas armadilhas com machos virgens co-específicos como atrativo.

\section{REFERENCES}

Bressan S.; Teles, M. M. C. and Carjaval, S. S. R. (1991), Influência das cores e formas das armadilhas na captura de Anastrepha spp. (Diptera: Tephritidae) em condições naturais. An. Soc Entomol. Brasil., 20, $19-26$.

Barbosa, F. R. (2001), Frutas do Brasil - Goiaba: Fitossanidade. Embrapa Semi-Árido (Petrolina, PE)Brasília: Embrapa Informação Tecnológica, pp. 2934.

Cboudbury, M. M. (2001), Frutas do Brasil - Goiaba: Pós-colheita. Embrapa Semi-Árido (Petrolina, PE) Brasília: Embrapa Informação Tecnológica, pp. 9-16. Facholi-Bendassolli, M. C. N and Uchôa-Fernandes, M. A. (2006), Comportamento sexual de Anastrepha 
sororcula Zucchi (Diptera, Tephritidae) em laboratório. Rev. Bras. Entomol., 50, 406-412.

Gonzaga-Neto, L. (2001), Frutas do Brasil - Goiaba: Produção. Embrapa Semi-Árido. (Petrolina, PE) Brasília: Embrapa Informações Tecnológicas, pp. 914.

Matias, M. F. O.; Oliveira, E. L.; Gertrudes, E. and Magalhães, M. M. A. (2005), Use of fibers obtained from cashew (Anacardium ocidentale, L) and guava (Psidium guajava) fruits for enrichment of food products. Brazil. Arch. Biol. Technol., 48, 143-150.

Nation, J. L. (1989), The role of pheromone in the mating system of Anastrepha fruit flies, p.189-205. In: Robison, A and Hooper S. (eds.). World crop pests, fruit flies: their biology, natural enemies and control. Amsterdam, Elsevier., v. 3A.

Perdomo, A. J.; Baranowski, R. M. and Nation, J. L. (1975), Recapture of virgin female Caribbean fruit flies from traps baited with males. Fla. Entomol., 58, 291-295.

Perdomo, A. J.; Nation, J. L. and Baranowski, R. M. (1976), Attraction of Female and Male Caribben

Fruit Flies to Food-Baited and Male-Baile Traps Under Field Conditions. Environ. Entomol., 5, 1208-1210.

Robarcker, D. C. and Garcia, J. A. (1990), Responses of laboratory-strain Mexican fruti flies, Anastrepha ludens (Diptera: Tephritidae), to combination of fermeting fruit odor and male-produced pheromone

Salles, L. A. B. (1992), Metodologia de criação de Anastrepha fraterculus (Wied., 1830) (Diptera: Tephritidae) em dieta artificial em laboratório. An. Soc. Entomol. Brasil., 21, 479-486.
Tardelli, C. A.; Godoy, W. A. C. and Mancera, P. F. A. (2004), Population dynamics of Musca domestica (Diptera: Muscidae): Experimental and theoretical studies at different temperatures. Brazil. Arch. Biol. Technol., 47, 775-783.

Uchôa-Fernandes, M. A. and Zucchi, R. A. (1999), Metodología da colecta de Tephritidae y Lonchaeidae frugívoros (Diptera: Tephritidae) y sus parasitoides (Hymenoptera). An. Soc. Entomol. Brasil., 28, 601610.

Uchôa-Fernandes, M. A.; Oliveira, I.; Molina, R. M. S. and Zucchi, R. A. (2003), Biodiversity of Frugivorous Flies (Diptera: Tephritoidea) Captured in Citros Groves, Mato Grosso do Sul Brasil. Neotrop. Entomol., 32, 239-246.

Vilela, E. F. and Della Lucia, T. M. C. (2001), Feromônios de insetos: biologia, química e emprego no manejo de pragas. $2^{\mathrm{a}}$ ed. Ribeirão Preto: FAPESPHolos, pp. 13-25. 